\title{
Administrative Challenges of Academic Heads of Department in Tertiary Institutions in Cross River State
}

\author{
Dr. (Mrs) Aniefiok Oswald Edet \\ Dr. (Mrs) Uduak Imo Ekpoh \\ Department of Educational Administration and Planning, \\ Faculty of Education, University of Calabar, Calabar
}

Doi:10.5901/mjss.2017.v8n2p129

\section{Abstract}

This study examined the Administrative Challenges of Academic Heads of Department in Universities in Cross River State, Nigeria. The study also sought to identify the strategies adopted by Heads of Departments to overcome the challenges. A descriptive survey design was utilized for the study. Four research questions guided the study. Data were collected from a sample of 129 HODs from University of Calabar (102) and Cross River University of Technology (27) using a questionnaire developed by the researchers and titled "Administrative Challenges of Academic Heads of Department Questionnaires (ACAHDQ). Data collected were analyzed with the aid of descriptive statistics (frequency and simple percentages). The findings revealed that the major challenges faced by HODs by ranking were funding 129 (100\%), meeting of deadlines 126 (98\%), delayed examination result 120 (93\%), excess workload $118(91.4 \%)$. Strategies used by them to combat these challenges as identified in the study included alternative sources of funding, setting deadlines early for submission of result by lecturers, working extra hours to cope with work load (schedule), extra incentives, improvisation etc. Based on the findings of the study, it was recommended that letters of appointment should be given to HODs with detailed specification of roles and responsibilities. Training retreat on professional management skills should be organized for them immediately they are appointed.

Keywords: Academic Heads of Department, Administrative Challenges, Strategies, Tertiary Institutions.

\section{Introduction}

Education all over the globe is undoubtedly the bedrock of all developmental strides. Governments of nations pay serious attention to it in order to achieve sustainable and progressive national development. In Nigeria the demand for education in recent years has been very high because the certificate gained at the expiration of school years gives citizens access to the world of work. So as a developing nation, Nigeria has taken cognizance of this, as well as the importance of education as a whole by establishing and structuring schools for the achievement of stated educational goals and objectives. The higher education system (universities) aims/objectives as spelt out by the Federal Republic of Nigeria (2008) and revised in 2013 are as follows:

(a) To contribute to national development through high level relevant manpower training.

(b) To develop and inculcate proper values for the survival of individual and society.

(c) To develop intellectual capability of individuals to understand and appreciate their local and external environments.

(d) To acquire both physical and intellectual skills which will enable individuals to be self-reliant and useful members of the society.

(e) To promote and encourage scholarship and community service.

(f) To forge and cement national unity and

(g) To promote national and international understanding and interaction (p. 50-51). 
To pursue the aforementioned objectives in tandem with universal best practices, effective leadership must be put in place in our universities if the aims must be achieved.

The structure of the university system sets the departments at the grassroot level of the organization. Bennett in Archibong and Edet (2009) describes it better by asserting that it is at the departmental level that the real institutional business gets conducted, it is here that teachers and learners make contact, that researchers find encouragement and direction and that many of the ways to contribute to the larger community are identified and explored. At the centre of these departmental levels are the academic Heads of Departments (HODs) whose positions carry with their multiplicity of responsibilities. These responsibilities according to Ashiomu (2009) range from handling matters about colleagues, students, the department, the faculty, visitors to administrative tasks. The head of department is therefore saddled with the responsibility of directing, guiding, coordinating and evaluating lecturers and activities appropriately to ensure good quality education and effective functioning of the department.

The head of department therefore should be very versatile by evolving different techniques in the management of both the human and material resources available. As the chief implementer of Nigerian Universities Commission (NUC) policies and the image maker of the department the head therefore must have the cognate experience and exposure required to effectively manage the department for the achievement of higher education objectives.

Bennett (1982) upholds this view that the head of department's job is the most difficult and demanding on campus. They bridge the gap between deans, departments and the university management. These multifarious responsibilities that go with the job description of heads of department are laced with challenges and constraints which constitute setbacks to effective management. Some of the challenges itemized by Archibong and Edet (2009) include;

(a) Role ambiguity

(b) Lack of training

(c) Insufficient resources/facilities

(d) Lapses in administrative procedure

(e) Poor remuneration

These and other challenges could overwhelm the HOD in the course of administration to the extent of hampering quality service delivering in the department and the university in general. It is therefore needful that HODs become aware of the expectation and demands of this position. Odigie (2009) identified ways of achieving exemplary and peculiar leadership to include; Challenging the process by looking for new ways of doing things, Inspiring a shared vision by looking into the future and communicating the organization's goals to the rest of the group, Enabling others to act by listening and encouraging others to participate, Modeling the way by first knowing the philosophy, goals and plans of the organization, Encouraging others to grow by acknowledging and rewarding their accomplishment, Taking notes and keeping good records and Improving on style, skills and competencies.

Abiodun-Oyedenji (2013) on his part asserted that the personal variables of heads of departments are also crucial determinants of their effective performance in the management of their departments. Supporting this view, Gauthier (2013) suggested that there is need to identify personal variables which will influence human behavior in terms of productivity. Idiong (2014) identified the personal variables to include; gender, age, marital status, ethnicity, religion, socio-economic status, educational qualification, professional rank, years of work experience. According to him, these variables play very important role, in the behavior of the administrative head and sometimes may determine their influence on the behavior and role performance of academic staff.

Attah (2015) conducted a study on school administrators' personal variables and management of indiscipline among teachers in secondary schools in Calabar Education Zone of Cross River State, Nigeria and found out that academic qualification, years of working experience, age and marital status significantly influenced the management of teaching and ethical related problems. This position was further buttressed by Ashimole \& Ahaiwe (2011) when they opined that the expected roles of school administrators by stakeholders include: acquisition of knowledge (educational qualification), experience (years of working experience) and a thorough understanding of people. According to them, there is a significant positive correlation between the above roles and leaders administrative effectiveness.

Given the high demand of responsibility, public expectation, complexity and difficulty of operation of the departments, the University management should take measures that would ensure the selection of persons of the right caliber for the position of HoDs. Lecturers should be carefully screened using such criteria as stated below before being appointed head of department. Criteria mentioned above include: demonstration of leadership qualities, must show evidence that they have plans for the department to which they will be appointed head, they must have knowledge of human resource management and management principles, personal characteristics which to some extent influences actions, behavior and feeling of an individual should also be considered. Supporting the above Akpan \& Archibong (2012) stated clearly that HoDs are vested with authority to influence the actions, behavior, beliefs and feelings of his 
subordinate and expect corporation.

In summary, delivery of quality education in universities cannot be achieved if the various departments that train the students are not properly managed. It is against this background that the researchers sought to identify some of the major challenges affecting the effective administration of academic departments in Universities in Cross River State. It also sought to identify the different strategies adopted by them to surmount the identified challenges.

\section{Statement of the Problem}

Nigeria, like other nations, needs universities to train the management workforce that would drive the nation's development engine. These university institutions in Nigeria are complex and multidimensional organizations which require tremendous imputs in terms of human and material resources. The University Academic Heads of Department are major players in the management of these imputs which is geared towards the achievement of university aims and objectives. It is expected that for HODs to create significant impact they must possess serious administrative and organizational skills for proper goal attainment. These skills could be leadership oriented, planning skills, communication skills, decision making skills, motivational skills etc. Unfortunately studies have indicated that most of them lack these skills for effectiveness. The attainment of the expected outcome of turning out well-educated work force is highly demanding and full of challenges, which may overwhelm or swallow the abilities of the HODs if they are not well equipped with the above mentioned skills through orientation and on-the-job training, seminars, workshops or retreat.

It has also been observed with dismay that most HODs are ignorant of their roles on resumption of duty and due to this ignorance, some costly administrative decisions are made, which sometimes may affect the smooth running of the departments. It is against this backdrop that the study is conducted to find out the challenges militating against the effective performance of these administrative duties or responsibilities.

\section{Purpose of the Study}

The main purpose of this study is to find out the challenges facing Academic Heads of Departments in Universities in Cross River State, Nigeria.

The specific concerns are:

1. To find out if HODs undergo training after appointment.

2. To find out the methods HOD adopt to familiarize themselves with the day-to-day running of the departments.

3. To identify major administrative challenges as reported by academic Heads of Department.

4. To investigate the strategies adopted to address the challenges

\section{Research Questions}

(1) What type of preparation do HODs have after appointment?

(2) What methods do HODs adopt to familiarize themselves with administration of the department?

(3) What are the identified administrative challenges reported by HODs?

(4) What strategies do HODs adopt to address these challenges?

\section{Method}

This study is a descriptive research design of the survey type. The target population involved all the academic Heads of Department of University of Calabar (102) from 11 faculties and Cross River University of Technology (27) from 8 faculties. One hundred and twenty nine (129) heads of department constituted the study sample.

The instrument tagged "Administrative Challenges of Academic Heads of Department Questionnaire" (ACAHODQ)" designed by the researchers and validated by experts in Educational Administration was used to collect data for the study. Section A of the research instrument sought for personal data. Section B contained 5 items, 2 had response options while the other 3 were open ended questions which required respondents to express their opinions/ideas.

The researchers administered the questionnaire personally. Respondents were given time to fill the questionnaire accordingly. The completed copies of the questionnaire were collected on the spot. One hundred percent (100\%) return rate was achieved. Data for the study were analyzed descriptive statistic (frequency and simple percentages). 


\section{Results}

\subsection{Research question 1: Do Heads of department undergo training after appointment?}

Table 1: HODs undergo training after appointment to prepare them for the job

\begin{tabular}{cccc}
\hline Response & Frequency & Percentage & $\%$ \\
\hline Yes & Nil & 0 & 00 \\
No & 129 & & 100 \\
Total & 129 & 100 & \\
\hline
\end{tabular}

Result presented on Table 1 indicates clearly that $129(100 \%)$ of the respondents from these universities do not have training or orientation before the commencement of these leadership position.

6.2 Research question 2: What methods do Heads of Department adopt to familiarize themselves with the administration of the department?

Table 2: Identified methods adopted to familiarize themselves on the job

\begin{tabular}{clcccc}
\hline \multirow{2}{*}{ S/N } & \multirow{2}{*}{ Items } & \multicolumn{2}{c}{ Responses } & Yes & \multirow{2}{*}{ No \% } \\
& & Yes & No & $\%$ & \\
\hline 1 & Consultations & 123 & 6 & 95.3 & 4.6 \\
2 & Studying of files/procedures & 121 & 8 & 94.0 & 6.2 \\
3 & Staff meetings & 115 & 14 & 89.1 & 11.0 \\
4 & Self-orientation & 50 & 79 & 39.0 & 61.2 \\
5 & Collaboration & 101 & 28 & 78.2 & 22.0 \\
6 & Student leaders participation & 79 & 50 & 61.2 & 39.0 \\
7 & Interaction with university staff & 96 & 33 & 74.4 & 26.0 \\
\hline
\end{tabular}

The results on Table 2 show the various strategies adopted by HODs to familiarize themselves with the job. The table indicates that the most widely used methods are consultation $(95.3 \%)$, studying of official files (94\%), staff meetings $(89.1 \%)$, collaboration $(78.2 \%)$, interaction with university staff $(74.4 \%)$ while self orientation was the least with thirty nine percent (39\%).

\subsection{Research question 3: What are the identified administrative challenges reported by Heads of Department.}

Table 3: Major administrative challenges by ranking

\begin{tabular}{lccccc}
\hline \multirow{2}{*}{ Items } & \multicolumn{2}{c}{ Response } & Yes & No & \multirow{2}{*}{ Rank } \\
& Yes & No & $\%$ & $\%$ & \\
\hline Funding & 129 & Nil & 100 & - & $1^{\text {st }}$ \\
Meeting deadlines & 126 & 3 & 98.0 & 2.0 & $2^{\text {nd }}$ \\
Delayed exam results & 120 & 9 & 93.0 & 7.0 & $3^{\text {rd }}$ \\
Excess workload & 118 & 11 & 91.4 & 9 & $4^{\text {th }}$ \\
Provision of facilities & 116 & 13 & 90.0 & 10.0 & $5^{\text {th }}$ \\
Students registration & 112 & 17 & 87.0 & 13.0 & $6^{\text {th }}$ \\
Student personnel administration & 102 & 27 & 79.0 & 21.0 & $7^{\text {th }}$ \\
Inefficient staff & 98 & 31 & 76.0 & 24.0 & $8^{\text {th }}$ \\
Conflict resolution & 80 & 49 & 62.0 & 38.0 & $9^{\text {th }}$ \\
Poor mentoring for junior staff & 68 & 61 & 53.0 & 47.0 & $10^{\text {th }}$ \\
\hline
\end{tabular}

Table 3 presents the major challenges faced by Academic Heads of Department. The table indicates that the highest percentage fall in funding which is $129(100 \%)$, followed by meeting deadlines $26(98 \%)$, delayed examination results 120 (93\%), excess workload $118(91.4 \%)$, provision of facilities $116(90 \%)$, students registration $112(87 \%)$, student personnel administration $102(79 \%)$, conflict resolution $80(62 \%)$ poor mentoring $68(53 \%)$. These were areas of highest constraints to effective management of academic departments. 


\subsection{Research question 4: What strategies do Heads of Department adopt to overcome the identified challenges?}

Table 4: Identified strategies adopted to overcome challenges

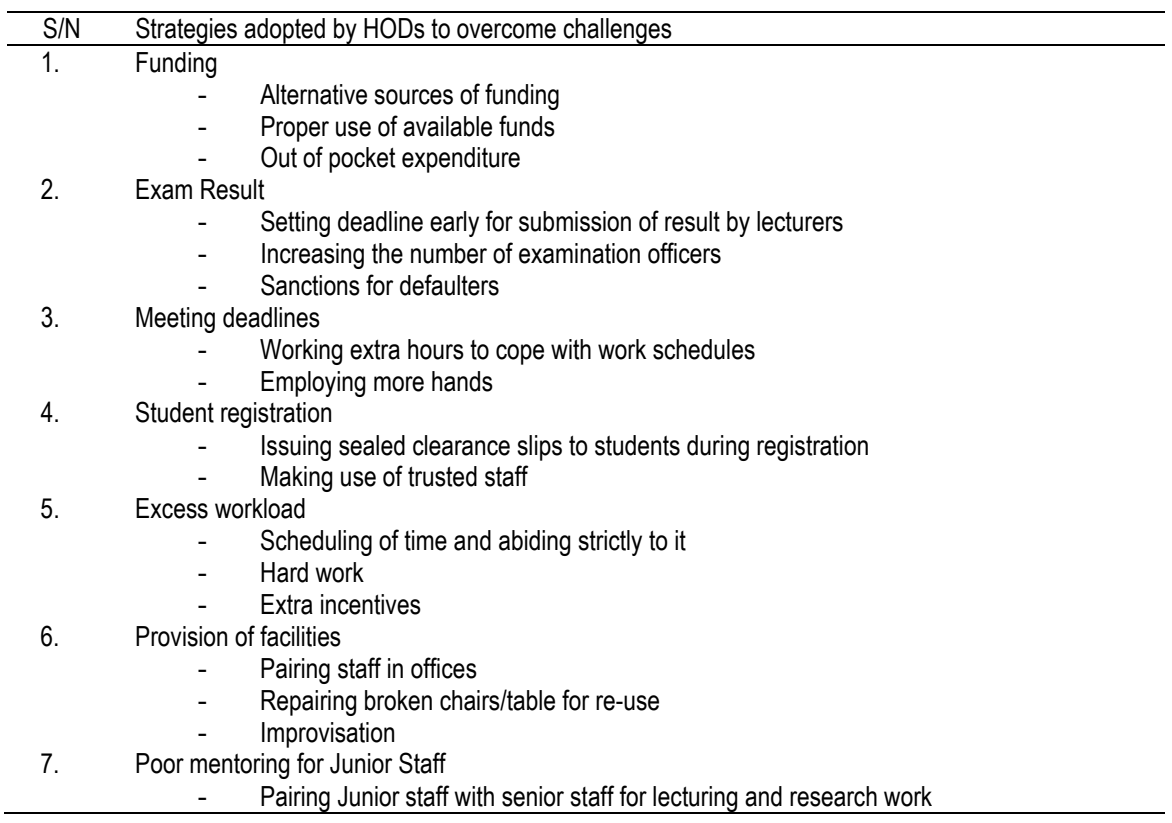

\section{Discussion of Results}

The study reveals that there is lack of training/orientation for academic heads of departments and unclear guidelines on their specific duties in the day-to-day administration of their departments. This finding indicates that the HODs adopt both the professional and non-professional strategies or approaches to combat the various challenges they face. The implication of this finding is that the adopted strategies mentioned in Table 2 may lead most HODs to adopt the mistakes of past HODs and end up making the same mistakes.

According to Inyang and Akpama (2002) training is the systematic development of knowledge, skills and attitudes required by the individual to perform adequately in a given task or job. Archibong and Edet (2009) also confirms the importance of training by asserting that staff training and staff development are related processes which organizations should not ignore. The study also indicated that there is an emerging need to trained personnel for management positions in the academic departments. Through training certain competencies will be identified and considered as important and necessary for managing departments in Nigerian universities. Such competencies as identified by Leach (1993) are

- Technical competencies

- Business competencies

- Interpersonal competencies

- Intellectual competencies

According to Akpan in Egwy (2007) training enables an employee to grow in the job, through the acquisition of a wide range of experience, increase in confidence through the exercise of varied and tested responsibilities. The above is aimed at enabling managers/administrators attain maximum proficiency through action, observation, study, reflection, experiment or initiatives. Thus what could be drawn from the foregoing.

The study also shows that the major challenges militating against the administrative effectiveness of HODs are funding, delayed examination results, meeting deadlines, provision of facilities etc. This is worrisome because those HODs without administrative skills or knowledge are bound to fumble, thereby hindering the achievement of the goal of education at the departmental level. It follows: therefore that the university has much at stake as far as a head of department's performance is concerned. There ought not to be mistakes, misjudgment or careless performance, this will 
weaken the departments (Peters, 1994). According to Archibong and Edet (2009), provision of standardized work condition, facilities, funds and reduction of workload can aid efficient performance and productivity.

Table 3 revealed that funding is a major or most challenging issue to the respondents, this can be seen in the $100 \%$ Yes answer for this item. This confirms an earlier assertion by Onucha (2007) that poor financing of education in Nigeria has posed unlimited threat to the success of educational breakthrough. The importance of funding in any organization cannot be overemphasized, therefore HODs perceiving this to be the most challenging aspect of the job should realize that university management alone cannot adequately fund all the departments. This implies that HODs could involve stakeholders in the funding of their departments, if well mobilized, Illo (2005) mentioned groups from the community that could assist in funding schools. Some of them include

- Alumni association

- Corporate bodies

- Private individuals

- Political bodies/groups

- NGOs

- Religious organizations.

\section{Conclusion}

Based on the findings of this study, the following conclusions were drawn. Academic Heads of Department are not trained or given orientation before the resumption of duty. Some major challenges confronting them were clearly identified and strategies for tackling the challenges evolved. It therefore follows that HODs' failure in achieving departmental goals and objectives results from improper preparation, and so under this condition, universities cannot live up to the expectation of producing high level manpower.

\section{Recommendations}

1. Letters of appointment should be given with detailed specification of roles and responsibilities to guide the HODs.

2. University management should facilitate the training of HODs on professional management skills and competences after appointment.

3. Adequate funds should be provided for proper management of the departments. While the HODs should also source for funds through Education Trust Fund (ETF) donations, endowment funds, grants and international agencies such as WHO, UNESCO, IMF, UNDP.

4. Employment of more lecturers in needed areas of specialization should be done by management. This will reduce workload on the HOD and examination officers. Mentorship will also be enhanced.

5. Physical facilities such as offices and working facilities should be provided to staff. This will reduce the pressure on the HOD.

6. The departments through HODs should increase their internally generated revenue through

- Establishment of business centres and other businesses

- Establishment of payback links with old boys/girls association of the department according to each graduating year. They should be called upon to make donations or fund a particular project of the department.

- For the achievement of university objectives, value should be added to the office of the chief executive of academic department in universities through carefully packaged training and orientation programmes which will help them to acquired management skills for the day-to-day running of the department.

\section{References}

Abiodun-Oyebanji, O. J. (2013). Personal variables as determinant of academic staff productivity in Nigerian universities. A paper presented at the joint staff and student seminar, Department of Education Management, University of Ibadan.

Akpan, C. P. \& Archibong, I. A. (2012). Personality variables as predictors of leadership role performance effectiveness of administrators of public secondary schools in Cross River State. International Education Studies 5(4), 213-221.

Archibong, A. I., \& Edet, A. O. (2009). Quality education and academic department management: some intervening factors. In A. Owan Enoh (Ed). Education and leadership in Nigeria. Annual Book of reading: Philosophy of Education Association of Nigeria. Pp. 3755 . 
Ashimole, A. O. \& Ahaiwe, C. N. (2011). The challenges of secondary school principlals in Umuahia Zone of Abia State, Nigeria in the $21^{\text {st }}$ Century. Nigerian Journal of Educational Administration and Planning. 14(2) 181-194.

Attach, E. E. (2015). School administrators personal variables and management of indiscipline among teachers in secondary schools in Calabar Education Zone of Cross River State, Nigeria. Unpublished M.Ed Thesis, University of Calabar, Calabar, Nigeria.

Bennett, J. B. (1982). Inside a Department chairperson. AGB reports, 5253.

Bennett, J. B. (1989). About department chairs. Eric Document Reproduction Services.

Egwu. E. I. (2007). Human resource development: An indispensable tool in managing technology, technical and vocational education in the Era of Globalization. In J. B. Babalolka, C. O. Akpa, \& A. O. Ayeni (2007) Eds, Managing technical and Vocational Education in the Era of Globalization. NAEAP.

Federal Republic of Nigeria (2008). National Policy on Education. Lagos: NERDC Publishers.

Gauthier, S. (2013). The role of environmental and personal variables influencing thermal comfort indices used in building simulation. $13^{\text {th }}$ Conference of International Building Performance Simulation Association, Humbery, France, August, 2013.

Idiong, M. U. (2014). Demographic variable and resident attitude towards solid waste management in Calabar Metropolis of Cross River State. An unpublished thesis submitted to Department of Curriculum and Teaching. University of Calabar.

Ilo, C. O. (2005). Towards an improved private sector and community participation in the provision and development of primary education in Lagos State. In Akpa, G. O., Udoh, S. U., \& Fagba Miye, E. O. (Eds) deregulating the provision and management of education in Nigeria. Jos: NAEAP.

Inyang, B. J., \& Akpama, A. M. (2002). Personnel management practice in Nigeria. Calabar. Merb Business Center.

Leach, J. A. (1993). Preparing tomorrows Business and industry trainers: appropriateness of the content of vocational teacher education programmes in Kirst Sowrtzel (1999) Ed. Journal of Vocation and Technical Education. Vol. 16, (1) http://scholarlib.vt.edujJVTEiv1'6n1/doolittle.htm1.

Odigie, V. O. (2009). Educational leadership challenges and option, styles and skills. In A Owan Enoh (Ed). Education and leadership in Nigeria. Annual Book of reading: Philosophy of Education Association of Nigeria. Pp. 112-125.

Onucha, J. C. (2007). Education financing in Nigeria. Implications for Technology Based Education. In J. B. Babalolka, C. O. Akpa, \& A. O. Ayeni (2007) Eds, Managing technical and Vocational Education in the Era of Globalization. NAEAP.

Oshiomu, A. O. (2009). Assessment of managerial stress of academic Department Heads in Tertiary Institution in Akwa Ibom and Cross River State. Studies in Education. Journal of the Faculty of Education. Ambrose Ali University. Ekpoma. 10 (182) 9-15.

Peters, G. F. (1994). Institutional responsibilities and chair training: The Michigean State Model. A DFL Bulletin, 25 (3) 49-103. 